日本一台湾研究交流「超高齢社会における高齢者のケアと支援のための ICT」 2020 年度 年次報告書

\begin{tabular}{|c|l|}
\hline 研究課題名 (和文) & $\begin{array}{l}\text { 独居高齢者の QOL のモニタリングと向上のための遠隔社 } \\
\text { 会的インタラクション支援 }\end{array}$ \\
\hline 研究課題名 (英文) & $\begin{array}{l}\text { Monitoring and Improving QOL of Elderly People Living } \\
\text { Alone with Remote Social Interaction Support。 }\end{array}$ \\
\hline 日本側研究代表者氏名 & 熊田 孝恒 \\
\hline & 所属・役職 \\
& 都大学 大学院情報学研究科・教授 \\
\hline 研究期間 & 2018 年 6 月 1 日〜 2022 年 3 月 31 日 \\
\hline
\end{tabular}

1。日本側の研究実施体制

\begin{tabular}{|l|l|l|}
\hline \multicolumn{1}{|c|}{ 氏名 } & \multicolumn{1}{|c|}{ 所属機関・部局・役職 } & \multicolumn{1}{|c|}{ 役割 } \\
\hline 熊田孝恒 & $\begin{array}{l}\text { 京都大学大学院 情報学研究科 } \\
\text { 教授 }\end{array}$ & 全体の統括、研究の実施 \\
\hline 中村裕一 & $\begin{array}{l}\text { 京都大学大学院 学術情報メデ } \\
\text { イアセンター 教授 }\end{array}$ & 全体の統括、研究の実施 \\
\hline
\end{tabular}

2。日本側研究チームの研究目標及び計画概要

本年度は、非同期遠隔共食を行うシステムを用い、若齢者や高齢者を対象とした実験を 行う。ユーザビリティの改善などを行い、高齢者にとつて使いやすいインタフェースを作 成する。さらには台湾チームにより開発中の口ボットインタフェースと統合し、ロボット インタフェースの効果を検証する。また、実際の食行動のビデオから、高齢者の発話や表 情の解析を行い、QOL や幸福感、認知機能の変化などとの関係を明らかにする。 


\section{3。 日本側研究チームの実施概要}

非同期遠隔共食を支援するシステムの開発を進めた。事前に録画された画像を食事の際に 視聴することで、非同期を実現するが、その際に、映像を撮影する人と被写体の両方を映像 メッセージに含めることが本研究の提案であり、それぞれの側の人の表情と、メッセージを 受け取った人の好感度に高い相関があること、表情が映像メッセージのもたらす効果の指標 の一つとして有用であることを確認してきた。特に、視聴者の表情からメッセージの満足度 を自動判定するために、深層学習による表情比較を基にした表情認識の研究を進め、笑顔の 認識に関して良い成果を得た。特に、0.1〜0.2 秒程度で起こるような小さな変化や人間で も識別が難しいような変化についても一定の精度が得られることを確認した。さらに、笑顔 だけでなく、困惑や嫌悪感といつたネガティブな感情の認識にも、笑顔の認識と同様な考え 方が適用できることを予備実験的に確認した。

また、食事時間中のコミュニケーションを支援するために、キーボードやタブレットのよ うな操作は最小限にとどめ、音声やジェスチャーなどでの操作が可能なインタフェースの検 討を行った。また、映像メッセージの取得のためには、話しかける相手がいたほうが話しや すい。このようなことから、閲覧映像を推薦したり、メッセージ記録を促したりしながら、 ユーザの操作を代行するロボットインタフェースの必要性やその機能について台湾側と議 論を進め、台湾側で既に構築を進めているロボットインタフェースやそのためのソフトウェ アとできるだけ共通部分を持たせた設計を行った。また、高齢者にも受け入れられやすい口 ボットの外観に関する国際比較研究も実施した。その結果、台湾においては、日本よりも人 間に近い外観の口ボットが高齢者には好まれる傾向があることが明らかとなつた。

さらに、食事行動と幸福感との関係に関する Web 調査を実施し、規則正しい食事の摂取 と幸福感の間に関連があることを見出した。さらに、加齢に伴う無力感（アパシー）が規則 正しい食事の摂取を阻害する可能性があることを見出した。今後、このような規則正しい食 事の摂取を支援する機能を共食支援システムに導入する予定である。 